\title{
Effect of Sowing Time on Growth, Phenology and Yield Attribute of Summer Groundnut (Arachis hypogaea L.)
}

\author{
Virender Pal, J.G. Patel ${ }^{*}$ and Anand Kumar \\ Department of Agricultural Meteorology, C.P. College of Agriculture, S. D. Agriculture \\ University, Sardarkrushinagar - 385 506, Gujarat, India \\ *Corresponding author
}

\begin{tabular}{|l|}
\hline Key w or d s \\
$\begin{array}{l}\text { Groundnut, Variety, } \\
\text { Date of sowing }\end{array}$ \\
\hline Article Info \\
\hline $\begin{array}{l}\text { Accepted: } \\
\text { 04 May } 2018 \\
\text { Available Online: } \\
\text { 10 June 2018 }\end{array}$ \\
\hline
\end{tabular}

A B S T R A C T

An investigation on effect of sowing time on growth, phenology and yield attribute of summer groundnut (Arachis hypogaea L.) was conducted at Agronomy Instructional Farm, Chimanbhai Patel College of Agriculture, Sardarkrushinagar Dantiwada Agricultural University, Sardarkrushinagar during summer season of 2012. Twelve treatment combinations with four dates of sowing $\left(01^{\text {st }}\right.$ February, $11^{\text {th }}$ February, $21^{\text {st }}$ February and $02^{\text {nd }}$ March) and three varieties (GG 2, GG 5 and GG 7) were tried in split plot design with four replications. The growth parameters, yield attributes and yield in terms of characters like plant population and test weight were non-significant and the plant height, number of branches, number of pods per plants, number of grains per plant, pod length, grain yield and stover yield were significantly influenced by the dates of sowing. The highest grain yield and stover yield were obtained from the third date of sowing $\left(25^{\text {th }}\right.$ February) and remained statistically at par with fourth date of sowing $\left(5^{\text {th }}\right.$ March). The variety GM 4 gave the highest yield due to more number of pods, number of grains per pod and 100 seed weight, followed by GM 3 variety which remained statistically at par. The duration of crop growth stages were influenced by the sowing dates. The delay in sowing reduced the total duration of the crop maturity period. The weather condition during the crop season was more or less normal and satisfactory.

\section{Introduction}

Groundnut (Arachis hypogaea L.) is an annual legume crop and a major oilseed of tropical and subtropical countries, which are also known as 'peanut' 'earthnut', 'monkey nut' and 'goobers'. It is the $13^{\text {th }}$ most important food crop and $4^{\text {th }}$ most important oilseed crop of the world. Groundnut is widely adapted to varying agro-climatic conditions and soils, which has made its cultivation possible in most of the tropical and sub-tropical countries in the world. It is commercially cultivated in about 100 countries located in between $40^{\circ} \mathrm{N}$ and $40^{\circ} \mathrm{S}$ latitudes. Groundnut is a $\mathrm{C}_{3}$ plant where photo-respiration is very high. It is deep and distinct tap roots with secondary and deeply spreading roots, makes it drought resistant to some extent. The dehiscence of the anthers takes place between 5 am and $6 \mathrm{am}$. Flowers open between 6 am and 8 am. Yield disparity between rabi and monsoon groundnut indicate that groundnut required warmth and bright sunshine hours for its 
growth and development. Minimum base temperature for the germination is $10^{\circ} \mathrm{C}$, while desirable is $20^{\circ} \mathrm{C}$. Optimum mean air temperature for vegetative growth is 25 to $30^{\circ} \mathrm{C}$. The temperature range for reproductive growth (pegging, pod formation and pod development) is 20 to $26^{\circ} \mathrm{C}$. Flower expression can proceed satisfactory up to a mean air temperature of $33^{\circ} \mathrm{C}$, but pod formation is retarded above $26^{\circ} \mathrm{C}$. The flowering of groundnut does not indicate any thermo periodicity. Higher temperature reduces the duration of the crop. Groundnut is usually, classified as a day neutral plant. Pod yield, however, is affected by day length. Long day (11 to $12 \mathrm{hrs)} \mathrm{particularly} \mathrm{at} \mathrm{the}$ beginning of the crop season, promote vegetative growth and less reproductive growth. In rabi, day length remain short during beginning and increase till harvest leading to higher pod yield. Relative humidity should be around 90 per cent in the first month of growth. Relative humidity more than 95 per cent and low temperature of $15^{\circ} \mathrm{C}$ for more than 10 hours lead to incidence of leaf spot. Crop production is a function of many variables, of environment, out of which weather is the most important. Among weather variables, temperature and rainfall are the most important factors, which affect the growth, productivity and adaptability of crops (Wallies et al., 1980). The duration of specific stages of growth shows direct relationship with temperature and for particular species, this duration may be predicted through summation of mean daily air temperature (Wang, 1960), because the duration of each growth phase determines the accumulation and partitioning of dry matter in different organs as well as crop responses to external environmental factors. This research is essential for the study of impact of weather parameters during different phases of growth on pod yield of summer groundnut. The information on relationship of weather parameters at different phenophases under irrigated condition will help the scientists and the farmers to increase yield of the crop. Hence, the experiment was proposed to find out the ideal dates of sowing for summer groundnut under the North Gujarat Agro climatic Zone.

\section{Materials and Methods}

The experiment was conducted at the Agronomy Instructional Farm, Chimanbhai Patel College of Agriculture, Sardarkrushinagar Dantiwada Agricultural University, Sardarkrushinagar during summer season of 2012. The soil of experimental plot was loamy sand in texture, low in organic carbon and available nitrogen, medium in available phosphorus and potassium status. Twelve treatment combinations with four dates of sowing $\left(1^{\text {st }}\right.$ February, $11^{\text {th }}$ February, $21^{\text {st }}$ February and $2^{\text {nd }}$ March) and three varieties (GG 2, GG 5 and GG 7) were tried in split plot design with four replications. The keep date of sowing in main plot and varieties as sub plot treatments. The crop was sown in line with spacing of $30 \times 10 \mathrm{~cm}$, using seed rate of $100 \mathrm{~kg} / \mathrm{h}$ and seed treatment with Rhizobium and Phosphate Solubilizing bacteria (PSB-10). A recommended dose of nitrogen (25 kg N/ha), phosphorus $(50 \mathrm{~kg}$ $\mathrm{P}_{2} \mathrm{O}_{5} / \mathrm{ha}$ ) and sulphur (40 kg S/ha) in form of Urea and DAP and Zinc sulphate for summer groundnut crop was applied as basal dose at the time of bed preparation.

Two interculturing and two hand weeding were carried out in summer groundnut crop to maintain weed free condition during crop season. The crop was free form major insect pests by taking suitable plant protection measures. The five plants from net plot were selected randomly and were tagged in each treatment plots for the purpose of measured observation. The treatments were evaluated on the basis of growth parameters like plant population $\left(\right.$ plant $/ \mathrm{m}^{2}$ ), on the basis of yield 
attribute like number of pod per plant, pod length measured with measuring scale, number of seed per pod, seed yield and haulm yield measured with weighing balance per net plot and the same was converted to seed yield per hectare. 100 seeds were counted from the sample and their weight (g) was recorded as test weight of each treatment. Phonological observation measured to decide the crop growth stages five plants from net plot were selected randomly and were tagged in each treatment plots for the purpose of identification of phenological stages. Whenever more than three plants from each plot attained a particular stage for consider for that stage. The same was compared with those from each of the experimental plots to generalize the crop growth stages from each date of sowing were recorded as date of emergence, branching, 50 per cent flowering, pod development and pod maturity. The recorded data were subjected to statistical analysis using the analysis of variance technique (Panse and Sukhatme, 1985).

\section{Results and Discussion}

\section{Growth parameters}

Data pertaining to growth parameters of summer groundnut are presented in Table 1. The data indicated that both initial and final plant population was non-significant.

\section{Yield attributes}

\section{Number of pods per plant}

The data pertaining to number of pods per plant as influenced due to different dates of sowing and varieties are furnished in Table 2 indicated that number of pods per plant was significantly affected by different dates of sowing. Significantly higher number of pod per plant (18.0) was recorded under third date of sowing $\mathrm{D}_{3}\left(21^{\text {st }}\right.$ February) followed by second date of sowing $\mathrm{D}_{2}\left(11^{\text {th }}\right.$ February). Significantly lower number of pods per plant (14.5) was recorded in $D_{1}$ sowing $\left(1^{\text {st }}\right.$ February). Sowing on $2^{\text {nd }}$ March $\left(\mathrm{D}_{4}\right)$ produced 16.6 per cent higher number of pod per plant over $D_{1}\left(1^{\text {th }}\right.$ February) sowing. Effect of varieties on number of pods per plant was significant variations.

Significantly higher number of pods per plant (17.7) was recorded in GG 5 variety $\left(\mathrm{V}_{2}\right)$, but it was statistically at par with GG 7 variety $\left(V_{3}\right)$. Significantly the lowest number of pods per plant (15.1) was recorded in $\mathrm{V}_{1}$ variety (GG 2). Interaction effect of dates of sowing and varieties did not realize significant effect on number of pods per plant. Present results are in accordance with the results reported Naphade et al., (1990) for different varieties of groundnut crop.

\section{0 seed weight $(g)$}

The data on effect of different dates of sowing and varieties on 100 seed weight (g) are presented in Table 2 indicated that 100 seed weight was not influenced due to different dates of sowing. 100 seed weight was significantly affected by different varieties. Significantly higher 100 seed weight (44.5 g) was observed in $\mathrm{V}_{2}$ variety (GG 5). However, it remained statistically at par with $\mathrm{V}_{3}$ variety (GG 7). Significantly the lowest 100 seed weight (40.6 g) was recorded in $\mathrm{V}_{1}$ variety (GG 2). Interaction effect of dates of sowing and varieties was not found non-significant with respect to 100 seed weight.

\section{Shelling per cent}

The data pertaining to shelling per cent as influenced due to different dates of sowing and varieties are furnished in Table 2 indicated that shelling per cent was significantly affected by different dates of sowing. 
Table.1 Effect of dates of sowing and varieties on initial and final plant (Per meter row length) population in summer groundnut

\begin{tabular}{|c|c|c|}
\hline Treatments & Initial plant population & Final plant population \\
\hline \multicolumn{3}{|c|}{ Main factor - Date of sowing (D) } \\
\hline$D_{1}-1^{\text {st }}$ Feb & 8.0 & 7.6 \\
\hline$D_{2}-11^{\text {th }}$ Feb & 9.0 & 8.6 \\
\hline $\mathrm{D}_{3}-21^{\text {st }}$ Feb & 9.3 & 8.9 \\
\hline$D_{4}-2^{\text {nd }}$ March & 8.4 & 8.0 \\
\hline S.Em. \pm & 0.09 & 0.08 \\
\hline C.D. at $5 \%$ & NS & NS \\
\hline C.V. \% & 12.3 & 12.3 \\
\hline \multicolumn{3}{|c|}{ Sub factor - Varieties (V) } \\
\hline$V_{1}-$ GG 2 & 8.4 & 7.8 \\
\hline$V_{2}-$ GG 5 & 9.0 & 8.7 \\
\hline $\mathrm{V}_{3}-\mathrm{GG} 7$ & 8.7 & 8.3 \\
\hline S.Em. \pm & 0.26 & 0.27 \\
\hline C.D. at $5 \%$ & NS & NS \\
\hline C.V. \% & 10.7 & 11.3 \\
\hline \multicolumn{3}{|l|}{ Interaction (D X V) } \\
\hline S. Em. \pm & 0.53 & 0.54 \\
\hline C.D. at $5 \%$ & NS & NS \\
\hline
\end{tabular}

Table.2 Effect of dates of sowing and varieties on number of pods per Plant, test weight (g), shelling (\%) and oil content (\%) in summer groundnut

\begin{tabular}{|c|c|c|c|c|}
\hline Treatments & $\begin{array}{c}\text { Number of pods } \\
\text { per plant }\end{array}$ & Test weight (g) & $\begin{array}{c}\text { Shelling } \\
(\%)\end{array}$ & $\begin{array}{l}\text { Oil content } \\
(\%)\end{array}$ \\
\hline \multicolumn{5}{|c|}{ Main factor - Date of sowing (D) } \\
\hline $\mathrm{D}_{1}-1^{\text {st }}$ Feb & 14.5 & 39.3 & 61.4 & 48.5 \\
\hline $\mathrm{D}_{2}-11^{\text {th }}$ Feb & 17.3 & 43.7 & 67.7 & 48.2 \\
\hline $\mathrm{D}_{3}-21^{\text {st }} \mathrm{Feb}$ & 18.0 & 44.3 & 71.0 & 47.8 \\
\hline $\mathrm{D}_{4}-2^{\text {nd }}$ March & 16.6 & 42.2 & 63.7 & 47.7 \\
\hline S.Em. \pm & 0.17 & 0.32 & 0.48 & 0.06 \\
\hline C.D. at $5 \%$ & 0.60 & NS & 1.64 & NS \\
\hline C.V. \% & 12.6 & 9.1 & 8.7 & 1.4 \\
\hline \multicolumn{5}{|c|}{ Sub factor - Varieties (V) } \\
\hline$V_{1}$ - GG 2 & 15.1 & 40.6 & 64.0 & 48.2 \\
\hline$V_{2}-$ GG 5 & 17.7 & 44.5 & 67.4 & 48.0 \\
\hline $\mathrm{V}_{3}-\mathbf{G G} 7$ & 17.0 & 42.1 & 66.4 & 47.8 \\
\hline S.Em. \pm & 0.40 & 0.91 & 0.88 & 0.17 \\
\hline C.D. at $5 \%$ & 1.21 & 2.73 & 2.63 & NS \\
\hline C.V. $\%$ & 8.5 & 7.5 & 4.6 & 1.3 \\
\hline \multicolumn{5}{|l|}{ Interaction (D X V) } \\
\hline S.Em. \pm & 0.81 & 1.83 & 1.76 & 0.35 \\
\hline C.D. at $5 \%$ & NS & NS & NS & NS \\
\hline
\end{tabular}


Table.3 Effect of date of sowing and varieties on pods yield and haulm yield in summer groundnut

\begin{tabular}{|c|c|c|}
\hline Treatments & Pod yield (kg/ha) & Haulm yield (Kg/ha) \\
\hline \multicolumn{3}{|c|}{ Main factor - Date of sowing (D) } \\
\hline$D_{1}-1^{\text {st }}$ Feb & 1043 & 1598 \\
\hline$D_{2}-11^{\text {th }}$ Feb & 1394 & 2073 \\
\hline $\mathrm{D}_{3}-21^{\mathrm{st}} \mathrm{Feb}$ & 1570 & 2220 \\
\hline $\mathrm{D}_{4}-2^{\text {nd }}$ March & 1231 & 1923 \\
\hline 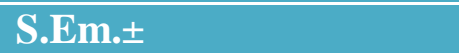 & 12.7 & 21.0 \\
\hline C.D. at $5 \%$ & 43.8 & $\overline{73.0}$ \\
\hline C.V. $\%$ & 11.6 & 12.8 \\
\hline \multicolumn{3}{|l|}{ Sub factor - Varieties (V) } \\
\hline $\mathrm{V}_{1}$ - GG 2 & 1250 & 1860 \\
\hline$V_{2}-$ GG 5 & 1378 & 2057 \\
\hline$V_{3}-$ GG 7 & 1301 & 1945 \\
\hline S.Em. \pm & 28.8 & 49.4 \\
\hline C.D. at $5 \%$ & 86.0 & 148.0 \\
\hline C.V.\% & 7.6 & 8.8 \\
\hline \multicolumn{3}{|l|}{ Interaction (D X V) } \\
\hline S.Em. \pm & 57.5 & 98.9 \\
\hline C.D. at $5 \%$ & NS & NS \\
\hline
\end{tabular}

Table.4 Influence of sowing date on duration of different phenological Phases (days) of in summer groundnut

\begin{tabular}{|c|c|c|c|c|c|c|}
\hline $\begin{array}{c}\text { Date of } \\
\text { Sowing }\end{array}$ & \multicolumn{7}{|c|}{ Phenophases (days) } & Total \\
\hline D1 & P1 & P2 & P3 & P4 & P5 & \\
\hline D2 & 10 & 28 & 18 & 18 & 45 & $\mathbf{1 1 9}$ \\
\hline D3 & 10 & 26 & 16 & 16 & 43 & $\mathbf{1 1 1}$ \\
\hline D4 & 9 & 25 & 15 & 14 & 42 & $\mathbf{1 0 5}$ \\
\hline
\end{tabular}

Significantly higher shelling per cent (71.0) was recorded under third date of sowing $\left(21^{\text {st }}\right.$ February). Significantly lower shelling per cent (61.4) was recorded in first date of sowing ( $1^{\text {st }}$ February). Effect of varieties on shelling per cent was significant variations. Significantly higher shelling per cent (67.4) was recorded under GG 5 variety $\left(\mathrm{V}_{2}\right)$, but it was statistically at par with GG 7 variety $\left(\mathrm{V}_{3}\right)$. Significantly the lowest shelling per cent (64.0) was recorded in $\mathrm{V}_{1}$ variety (GG 2).
Interaction effect of dates of sowing and varieties was not found significant with respect to shelling per cent.

\section{Yield}

\section{Oil content $(\%)$}

The data pertaining to oil content (\%) as influenced by different dates of sowing and varieties are furnished in Table 2 indicated 
that oil content (\%) was non-significantly affected by different dates of sowing. The results indicated that oil content (\%) was nonsignificantly to different varieties. Interaction effect between dates of sowing and varieties on oil content $(\%)$ was non-significant.

\section{Pod yield (kg/ha)}

The data pertaining to pod yield as influenced due to different dates of sowing and varieties are furnished in Table 3. It is evident that pod yield was significantly influenced due to dates of sowing. Sowing on $21^{\text {st }}$ February $\left(D_{3}\right)$ resulted into significantly higher pod yield (1570 kg/ha), Lower seed yield (1043 kg/ha) was obtained with sowing on $1^{\text {th }}$ February $\left(D_{1}\right)$ followed by the $2^{\text {nd }}$ March $\left(D_{4}\right)(1231$ $\mathrm{kg} / \mathrm{ha})$ and $11^{\text {th }}$ February $\left(\mathrm{D}_{2}\right) 1394 \mathrm{Kg} / \mathrm{ha}$. The results indicated significant variations on seed yield by different varieties. Significantly higher pod yield $(1378 \mathrm{~kg} / \mathrm{ha})$ was recorded under GG 5 variety $\left(\mathrm{V}_{2}\right)$, but it was statistically at par with GG 7 variety $\left(\mathrm{V}_{3}\right)$. Significantly the lowest pod yield (1250 $\mathrm{kg} / \mathrm{ha}$ ) was recorded in $\mathrm{V}_{1}$ variety (GG 2). This may be due to favourable climatic condition (i.e. temperature, relative humidity, vapour pressure and bright sunshine hours etc.) with less weed competition and has incidence of pest and disease and maximum temperature ranged between 28.5 to $33.0^{\circ} \mathrm{C}$ during germination, 27.8 to $38.0^{\circ} \mathrm{C}$ during flowering, 35.0 to $40.7^{\circ} \mathrm{C}$ during pegging, 34.2 to $40.0^{\circ} \mathrm{C}$ during pods development and 36.0 to $41.2^{\circ} \mathrm{C}$ during pod maturity while minimum temperature ranged between 9.0 to $12.1^{\circ} \mathrm{C}$ during germination, 7.5 to $19.0^{\circ} \mathrm{C}$ during flowering, 16.5 to $23.1^{\circ} \mathrm{C}$ during pegging, $\quad 19.0$ to $23.1^{\circ} \mathrm{C}$ during pods development and 17.5 to $26.7^{\circ} \mathrm{C}$ during pod maturity. Interaction effect of dates of sowing and varieties was non-significant with respect to pod yield. These findings in the present investigation are in accordance with the findings Jadhav et al., (1990)

\section{Haulm yield (kg/ha)}

The data pertaining to haulm yield as influenced due to different dates of sowing and varieties are furnished in Table 3 revealed significant variations on haulm yield due to different dates of sowing. Significantly higher haulm yield $(2220 \mathrm{~kg} / \mathrm{ha})$ was recorded under third date of sowing (21 ${ }^{\text {st }}$ February). Significantly lower haulm yield $(1598 \mathrm{~kg} / \mathrm{ha})$ was recorded in first date of sowing $\left(1^{\text {st }}\right.$ February). The results presented in Table 4 indicated significant variations on haulm yield by different varieties. Significantly higher haulm yield $(2057 \mathrm{~kg} / \mathrm{ha})$ was recorded under GG 5 variety $\left(\mathrm{V}_{2}\right)$, but it was statistically at par with GG 7 variety $\left(\mathrm{V}_{3}\right)$. Significantly the lowest haulm yield $(1860 \mathrm{~kg} / \mathrm{ha})$ was recorded in GG 2 variety $\left(\mathrm{V}_{1}\right)$. Interaction effect between dates of sowing and varieties on haulm yield was non-significant. These results are in close agreement with the findings of Bhosale et al., (1986) and Jadhav et al., (1994).

\section{Crop phenology}

The observation on crop phenological events reflects the influence of weather elements on crop growth and development. In the present study, the occurrence of different phenological events viz., germination, flowering, pegging, pod development, pod maturity were recorded. The phenological calendar for groundnut crop for four dates of sowing in the present investigation is presented in Table 4. Phasic duration at different phenophases of groundnut decreased with delay in sowing from February 1 to March 2. February 1 sown crop took longer duration for maturity (119 days) than the later sown crop in all cultivars due to fulfillment of thermal unit requirements in more days. The days to maturity decreased gradually with the delay in sowings. This may be due to increase in temperature and photothermal environment 
encountered by the crop during the growth period. However, reduction in duration (99 days) under fourth date of sowing may be mainly due to expose of the crop to higher maximum temperature $\left(40.4{ }^{\circ} \mathrm{C}\right)$ after flowering.

\section{References}

Bhosale, S. G., Shelke, V. B., Dhoble, M. V. and Raikheikar, S. V. (1986). Effect of sowing dates on groundnut varieties in summer season. Journal of Maharashtra Agriculture University 12 (2): 197-198.

Jadhav, A. S., Mundhe, M. S and Gaikwad, C. B. (1990). Influence of sowing dates of summer groundnut varieties. Journal of
Maharashtra Agricultural University 15(2): 214-217.

Naphade, D. S. Sawarkar, P. G. and Kene, H. K. (1990). Effect of sowing dates on yield of summer groundnut. Journal of Maharashtra Agricultural University 18 (1): 157.

Panse, V. G. and Sukhatme P. V. (1985): Statistical methods for agricultural workers. ICAR, New Delhi, pp: 359.

Wallies, E. S., Byth, D. E. and Saxena, O. P. (1980). Flowering response of thirty seven early maturing lines of pigeonpea. In Proc. International Symposium on Pigeonpea. 15-19 Dec, ICRISAT, Hyderabad, pp: 143-150.

Wang, J. Y. (1960). A critique of the heat unit approaches to plant response studies. Ecology 41: 785-790.

\section{How to cite this article:}

Virender Pal, J.G. Patel and Anand Kumar. 2018. Effect of Sowing Time on Growth, Phenology and Yield Attribute of Summer Groundnut (Arachis hypogaea L.). Int.J.Curr.Microbiol.App.Sci. 7(06): 715-721. doi: https://doi.org/10.20546/ijcmas.2018.706.084 